\title{
Article \\ Effects of Adding Laccase to Bacterial Consortia Degrading Heavy Oil
}

\author{
Xiaoli Dai ${ }^{1, * \mathbb{D}}$, Jing $\mathrm{Lv}^{2}$, Wenxia Wei ${ }^{1}$ and Shaohui Guo ${ }^{2}$ \\ 1 Beijing Key Laboratory of Remediation of Industrial Pollution Sites, Institute of Resource and Environment, \\ Beijing Academy of Science and Technology, Beijing 100089, China; 13693649137@163.com \\ 2 State Key Laboratory of Heavy Oil Processing, Beijing Key Laboratory of Oil and Gas Pollution Control, \\ College of New Energy and Materials, China University of Petroleum-Beijing, Beijing 102249, China; \\ lvjing@cup.edu.cn (J.L.); cupgsh@163.com (S.G.) \\ * Correspondence: daixiaoli2007@163.com
}

check for

updates

Citation: Dai, X.; Lv, J.; Wei, W.; Guo, S. Effects of Adding Laccase to Bacterial Consortia Degrading Heavy Oil. Processes 2021, 9, 2025. https://doi.org/10.3390/pr9112025

Academic Editor: Alexey V. Vakhin

Received: 16 September 2021

Accepted: 10 November 2021

Published: 12 November 2021

Publisher's Note: MDPI stays neutral with regard to jurisdictional claims in published maps and institutional affiliations.

Copyright: (c) 2021 by the authors. Licensee MDPI, Basel, Switzerland. This article is an open access article distributed under the terms and conditions of the Creative Commons Attribution (CC BY) license (https:// creativecommons.org/licenses/by/ $4.0 /)$.

\begin{abstract}
High-efficiency bioremediation technology for heavy oil pollution has been a popular research topic in recent years. Laccase is very promising for the remediation of heavy oil pollution because it can not only convert bio-refractory hydrocarbons into less toxic or completely harmless compounds, but also accelerate the biodegradation efficiency of heavy oil. However, there are few reports on the use of laccase to enhance the biodegradation of heavy oil. In this study, we investigated the effect of laccase on the bacterial consortia degradation of heavy oil. The degradation efficiencies of bacterial consortia and the laccase-bacterial consortia were $60.6 \pm 0.1 \%$ and $68.2 \pm 0.6 \%$, respectively, and the corresponding heavy oil degradation rate constants were 0.112 day $^{-1}$ and 0.198 day $^{-1}$, respectively. The addition of laccase increased the heavy oil biodegradation efficiency $(p<0.05)$ and biodegradation rate of the bacterial consortia. Moreover, gas chromatography-mass spectrometry analysis showed that the biodegradation efficiencies of the laccase-bacterial consortia for saturated hydrocarbons and aromatic hydrocarbons were $82.5 \pm 0.7 \%$ and $76.2 \pm 0.9 \%$, respectively, which were $16.0 \pm 0.3 \%$ and $13.0 \pm 1.8 \%$ higher than those of the bacterial consortia, respectively. In addition, the degradation rate constants of the laccase-bacterial consortia for saturated hydrocarbons and aromatic hydrocarbons were $0.267 \mathrm{day}^{-1}$ and 0.226 day $^{-1}$, respectively, which were 1.07 and 1.15 times higher than those of the bacterial consortia, respectively. The degradation of C15 to C35 n-alkanes and 2 to 5-ring polycyclic aromatic hydrocarbons by laccase-bacterial consortia was higher than individual bacterial consortia. It is further seen that the addition of laccase significantly improved the biodegradation of long-chain n-alkanes of C22-C35 $(p<0.05)$. Overall, this study shows that the combination of laccase and bacterial consortia is an effective remediation technology for heavy oil pollution. Adding laccase can significantly improve the heavy oil biodegradation efficiency and biodegradation rate of the bacterial consortia.
\end{abstract}

Keywords: heavy oil pollution; bioremediation; laccase; bacterial consortia; degradation

\section{Introduction}

The use of heavy oil is rapidly growing to meet escalating energy demands; consequently, the pollution resulting from accidents involving heavy oil are also increasing annually [1,2]. Compared with conventional crude oil, heavy oil has a much higher density and viscosity, and it contains high-molecular-weight hydrocarbons (especially highly polycyclic aromatic hydrocarbons), heterocyclic compounds, and heavy metals [3,4]. Moreover, heavy oil pollution causes severe and lasting harm to both the ecological environment and human health. Therefore, there is an urgent need for efficient remediation technologies for heavy oil pollution [5-7].

Microbial remediation technology based on the addition of efficient bacteria is promising for the treatment of heavy oil pollution owing to its low cost and prevention of secondary pollution [8]. However, it is difficult for high-efficiency bacteria to adapt to actual 
heavy oil pollution environments and survive several of the biological and abiotic restrictions, such as physical and chemical requirements, as well as indigenous microbial competition $[9,10]$. This results in the slow start-up of the bioremediation process. In addition, the high content of refractory organic compounds, such as long-chain aliphatic hydrocarbons and polycyclic aromatic hydrocarbons (PAHs) in heavy oil, also brings about new challenges to the microbial remediation of heavy oil pollution $[4,11]$. The biodegradability of hydrocarbons in heavy oil generally decreases in the following order: n-alkanes, branched alkanes, branched alkenes, low molecular weight n-alkyl aromatics, monoaromatics, cycloalkanes, polycyclic aromatic hydrocarbons (PAHs), and asphaltene [4]. It has been reported that enzymes can quickly start the biodegradation of toxic and refractory pollutants. Laccase, oxidases, reductases, depolymerases, peroxidases, dioxygenases, and dehydrogenases are utilized for the degradation of different toxic environmental pollutants (PAHs, dyes, heavy metals, plastics, pesticides, etc.) [12-14]. The advantages of enzymatic degradation of toxic environmental pollutants include highly flexible operational conditions; ease of control; a rapid, cost-effective, and highly specific process; no need of nutrient supply; reduced mass transfer limitation; resistance to protozoa predation and toxic pollutants, etc. [13]. Therefore, it can be applied to both in situ bioremediation and ex situ bioremediation.

Several recent studies have demonstrated the potential of laccase to degrade hydrocarbons [15-18]. Laccase (EC 1.10.3.2), a polyphenol oxidase, is a well-known biocatalyst for oxidizing various PHAs, phenols, and aromatic amines to form quinones or oligomers, as well as to reduce molecular oxygen to produce water [15]. Wu et al. [19] used laccase to treat aged PAH-contaminated soils. Their results showed that laccase could degrade 15 priority PAHs (specified by the U.S. Environmental Protection Agency) to varying degrees $(11 \%$ to $86 \%)$ after $24 \mathrm{~h}$. Bautista et al. [20] used immobilized laccase to degrade $82 \%$ naphthalene, $73 \%$ phenanthrene, and 55\% anthracene in PAHs. Kucharzyk et al. [14] demonstrated that the co-immobilized preparation of laccase and manganese peroxidase can effectively improve the degradation activity of petroleum-degrading microorganisms in contaminated sites and significantly promote the biodegradation of petroleum hydrocarbons, especially PAHs. Laccase has high activity in degrading hydrocarbons; however, there are few reports on the degradation of heavy oil by microorganisms combined with laccase. Liu et al. [21] demonstrated that bacteria-fungi (secreting laccase) joint remediation can effectively degrade petroleum hydrocarbons contained in soil, and the higher the laccase production and activity, the more stable the growth situation of white-rot fungi, yielding better TPH degradation rates and remediation results. This motivated us to utilize bench-scale experimental systems to investigate the effectiveness of laccase in heavy oil biodegradation processes.

This study investigated the effect of adding laccase on the bacterial consortia degradation of heavy oil. The heavy oil degradation efficiency and kinetics of the bacterial consortia and laccase-bacterial consortia were studied. Changes in saturated hydrocarbons and aromatic hydrocarbons during heavy oil biodegradation were characterized by gas chromatography-mass spectrometry (GC-MS).

\section{Materials and Methods}

\subsection{The Heavy Oil Composition}

The experimental oil was Venezuelan extra-heavy crude oil with diluents, containing $35.33 \%$ saturated hydrocarbons, $34.11 \%$ aromatic hydrocarbons, $19.87 \%$ asphaltenes, and $12.27 \%$ resins. Its API degree was 16 . It was sourced from the PetroChina Liaohe Petrochemical Company, located in Liaoning Province, China.

\subsection{Heavy Oil-Degrading Bacterial Consortia}

The heavy oil-degrading bacterial consortia were constructed by our research group, and were composed of Brevibacillus sp. DL-1, Bacillus sp. DL-13, and Acinetobacter schindleri DL-34, which all are biosurfactant producing bacteria and heavy oil degrading bacteria. 
They can degrade $60.75 \%$ heavy oil in 8 days. The bacterial strain was separately incubated in a rotatory shaker $(160 \mathrm{rpm})$ under aerobic conditions at $30{ }^{\circ} \mathrm{C}$ for $24 \mathrm{~h}$. Cells in the Luria-Bertani (LB) medium were harvested by centrifugation at $5000 \mathrm{rpm}$ for $10 \mathrm{~min}$ and washed three times, and the $\mathrm{OD}_{600}$ was adjusted to 0.8 using distilled saline solution. The composition and heavy oil degradation characteristics of the bacterial consortia were reported in a previous study [22]. The bacterial consortia were constructed by optimizing the degradation efficiency of heavy oil.

\subsection{Crude Laccase Solution}

The crude laccase solution was prepared using genetic engineering technology. The laccase-encoding gene was amplified from the total DNA of Bacillus subtilis subsp. Subtilis str. 168 using specific primers. The amplified laccase-encoding gene was then gel-purified (iNtRON) and ligated into the pMD19-T vector (TAKARA). The recombinant plasmid pMD19-T carrying the laccase-encoding gene was transferred to E. coli $\mathrm{DH} 5 \alpha$ via electroporation, and the genetically engineered bacteria containing the laccase-encoding gene were obtained via screening with blue and white spots. Plasmid DNA was extracted from selected clones using a plasmid DNA extraction kit (Sangon Biotech Co., Ltd., Shanghai, China) according to the manufacturer's instructions. The laccase-encoding gene was amplified from the plasmid DNA via polymerase chain reaction with specific primers and then sequenced (BGI Biotech Co., Ltd., Beijing, China).

After the laccase-encoding gene sequence was corroborated in the recombinant pMD19-T vector, the vector containing the laccase-encoding gene was digested using EcoR I and BamH I and then ligated into the corresponding sites of the pET28a (+) vector, which was initially digested using the same restriction enzymes. The ligated mixture was then transformed into the protein expression strain E. coli BL21 (DE3). Laccase was prepared via the fermentation of the genetically engineered E. coli BL21 (DE3) for laccase overexpression, and the fermentation broth was centrifuged to collect cells at a low temperature. Subsequently, the cells were subjected to sonication for $10 \mathrm{~min}$ on ice in pulses of $5 \mathrm{~s}$ on and $10 \mathrm{~s}$ off at $50 \%$ amplitude. Finally, the cell lysate was centrifuged at $4{ }^{\circ} \mathrm{C}$ and $12,000 \times g$ for $30 \mathrm{~min}$ to remove cell debris. The supernatant was used as the crude laccase solution.

\subsection{Culture Medium}

The LB medium contained $10 \mathrm{~g} / \mathrm{L}$ peptone, $10 \mathrm{~g} / \mathrm{L}$ beef extract, and $10 \mathrm{~g} / \mathrm{L} \mathrm{NaCl}$. The medium was adjusted to $\mathrm{pH} 7.0$ and sterilized by autoclaving at $121^{\circ} \mathrm{C}$ for $30 \mathrm{~min}$ before use. Solid LB medium was prepared by adding $20 \mathrm{~g}$ of agar to $1 \mathrm{~L}$ of LB.

The mineral salt medium (MSM) contained $5 \mathrm{~g} / \mathrm{L}\left(\mathrm{NH}_{4}\right)_{2} \mathrm{SO}_{4}, 3 \mathrm{~g} / \mathrm{L} \mathrm{KH}_{2} \mathrm{PO}_{4}, 2 \mathrm{~g} / \mathrm{L}$ $\mathrm{Na}_{2} \mathrm{HPO}_{4} \cdot 2 \mathrm{H}_{2} \mathrm{O}, 0.7 \mathrm{~g} / \mathrm{L} \mathrm{MgSO}_{4} \cdot 7 \mathrm{H}_{2} \mathrm{O}$, and $1 \mathrm{~mL}$ of trace element solution. The medium was adjusted to $\mathrm{pH} 7.0$ and sterilized by autoclaving at $121^{\circ} \mathrm{C}$ for $30 \mathrm{~min}$ before use. Solid MSM medium was prepared by adding $20 \mathrm{~g}$ of agar to $1 \mathrm{~L}$ of MSM.

The trace element solution contained $50 \mathrm{mg} / \mathrm{L} \mathrm{FeCl}_{3} \cdot 6 \mathrm{H}_{2} \mathrm{O}, 10 \mathrm{mg} / \mathrm{L} \mathrm{ZnSO} \cdot 7 \mathrm{H}_{2} \mathrm{O}$, $2 \mathrm{mg} / \mathrm{L} \mathrm{CaCl}_{2}, 0.5 \mathrm{mg} / \mathrm{L} \mathrm{MnCl}_{2} \cdot 4 \mathrm{H}_{2} \mathrm{O}$, and $0.5 \mathrm{mg} / \mathrm{L} \mathrm{CuSO}_{4}$. The medium was filtered and sterilized with a $0.22 \mu \mathrm{M}$ filter membrane and stored for later use.

The heavy oil medium contained $0.01 \mathrm{~g}$ heavy oil and $30 \mathrm{~mL}$ MSM. The culture medium was sterilized using high-temperature and high-pressure steam at $121{ }^{\circ} \mathrm{C}$ for $30 \mathrm{~min}$ and stored for later use.

\subsection{Heavy Oil Biodegradation}

The bacterial consortia were inoculated in $30 \mathrm{~mL}$ of the MSM medium with $0.01 \mathrm{~g}$ of heavy crude oil. The vials were incubated in a rotatory shaker (160 rpm) under aerobic conditions at $30{ }^{\circ} \mathrm{C}$ for $14 \mathrm{~d}$. All experiments were performed in triplicate. The residual heavy oil in each vial was extracted using $40 \mathrm{~mL}$ of $\mathrm{CCl}_{4}$ at time intervals of $0,2,4,6,8$, and $10 \mathrm{~d}$. 
The crude laccase enzyme solution and bacterial consortia were inoculated in $30 \mathrm{~mL}$ of the MSM medium with $0.01 \mathrm{~g}$ of heavy crude oil. The vials were incubated in a rotatory shaker $(160 \mathrm{rpm})$ under aerobic conditions at $30{ }^{\circ} \mathrm{C}$ for $14 \mathrm{~d}$. The residual heavy oil in each vial was extracted using $40 \mathrm{~mL} \mathrm{CCl}_{4}$ at time intervals of $0,2,4,6,8$, and $10 \mathrm{~d}$.

\subsection{Heavy Oil Degradation Efficiency and Degradation Kinetics}

The heavy oil in the extract was measured using an infrared oil content analyzer (OIL-460, Beijing ChinaInvent Instrument Tech. Ltd., Beijing, China) according to the national standard method in China [23]. The residual heavy oil in each vial was extracted using $40 \mathrm{~mL}$ of $\mathrm{CCl}_{4}$ for quantification and CG-MS analysis, and the extraction process was repeated three times. The heavy oil degradation efficiency was calculated using Equation (1):

$$
\text { Heavy oil degradation efficiency }(\%)=\frac{C_{0}-C_{t}}{C_{0}} \times 100 \%
$$

where $C_{0}$ is the initial heavy oil concentration and $C_{t}$ is the heavy oil concentration after $\mathrm{t}$ days of incubation.

The microbial degradation of heavy oil is typically expressed using first-order kinetics [24,25], as given in Equation (2):

$$
\mathrm{LnC}_{\mathrm{t}}=-\mathrm{kt}+\mathrm{b}
$$

where $C_{t}$ is the heavy oil concentration after $t$ days of incubation, $k$ is the biodegradation rate constant $\left(\mathrm{day}^{-1}\right), \mathrm{t}$ is the time (day), and $\mathrm{b}$ is the fitting constant.

\subsection{Separation and GC-MS Analysis of the Saturated and Aromatic Hydrocarbons of Heavy Oil}

The composition of heavy oil is complex. According to its chemical structure, there are four main components of heavy oil: saturated hydrocarbons, aromatic hydrocarbons, resins, and asphaltenes [26]. The residual heavy oil was separated using column chromatography. The detailed method is as follows: first, $0.7 \mathrm{~g}$ of heavy oil was dried using nitrogen, redissolved in petroleum ether $\left(30^{\circ} \mathrm{C}\right.$ to $\left.60{ }^{\circ} \mathrm{C}\right)$, and then left to stand and precipitate. The petroleum ether solution was filtered to produce colorless liquid using absorbent cotton, which was then dried with nitrogen, concentrated to $5 \mathrm{~mL}$, and separated via column chromatography. The adsorbent of the stationary phase was active silica gel/active alumina with a mass ratio of 3:2. The former was extracted with chloroform, boiled with distilled water, and activated in an electric drying oven; the latter was activated and dried in a muffle furnace. The alkanes and aromatics were eluted with petroleum ether $\left(30^{\circ} \mathrm{C}\right.$ to $\left.60{ }^{\circ} \mathrm{C}\right)$ and petroleum ether $\left(30^{\circ} \mathrm{C}\right.$ to $\left.60^{\circ} \mathrm{C}\right) /$ dichloromethane $(1: 2, v / v)$ and analyzed using GC-MS with n- $\mathrm{C}_{24} \mathrm{D}_{50}$ and DBT- $\mathrm{D}_{8}$ as standards, respectively. The detailed operation parameters can be found in a previous study by Cai et al. [27].

\section{Results}

\subsection{Crude Laccase Solution Preparation for Heavy Oil Degradation}

The use of crude laccase has major advantages over the use of purified laccase in terms of industrial scale operations. This is because it reduces the downstream purification processes, and the synergistic action of the mixture provides a more efficient oxidation than the purified enzyme [28,29]. Therefore, the crude laccase solution was used for heavy oil microbial degradation in this study. This solution was prepared via the overexpression of laccase in genetically engineered E. coli BL21, and its activity was $9.5 \pm 0.7 \mathrm{U} / \mathrm{mL}$, with ABTS as the substrate. The activity of laccase was significantly increased to 1.5 times higher than that of the wild strain $(6.3 \pm 0.3 \mathrm{U} / \mathrm{mL})$. This result is consistent with the results of previous studies $[30,31]$. It has been widely demonstrated that the laccase heterologously expressed in E. coli BL21 has higher activity and yield than that found in wild strains. 


\subsection{Heavy Oil Degradation Efficiency and Kinetics of the Laccase-Bacterial Consortia}

Figure 1 shows that after $10 \mathrm{~d}$, the heavy oil degradation efficiency of the bacterial consortia was $60.6 \pm 0.1 \%$, and the heavy oil concentration decreased from $223.6 \pm 2.8 \mathrm{mg} / \mathrm{L}$ to $88.1 \pm 0.4 \mathrm{mg} / \mathrm{L}$. Considering the laccase-bacterial consortia, the heavy oil degradation efficiency was $68.2 \pm 0.6 \%$, and the heavy oil concentration decreased from $223.6 \pm 2.8 \mathrm{mg} / \mathrm{L}$ to $71.1 \pm 0.9 \mathrm{mg} / \mathrm{L}$. The heavy oil degradation efficiency of the laccase-bacterial consortia was $7.6 \pm 0.6 \%$ higher than that of the bacterial consortia. Laccase has no obvious degradation effect on heavy oil. This trend demonstrates that the laccase cannot be used for heavy oil degradation alone, but can catalyze the further degradation of heavy oil degradation products by bacteria consortia. Furthermore, laccase enhanced the heavy oil biodegradation rate (Figure 2). The kinetic constants of the heavy oil degradation of the bacterial consortia and the laccase-bacterial consortia were 0.112 day $^{-1}$ and 0.198 day $^{-1}$, respectively; the laccase action increased the degradation rate by 1.9 times. These results show that laccase can improve the heavy oil biodegradation efficiency and biodegradation rate by directly participating in the initial oxygenation of PAHs or other petroleum hydrocarbons [32,33].

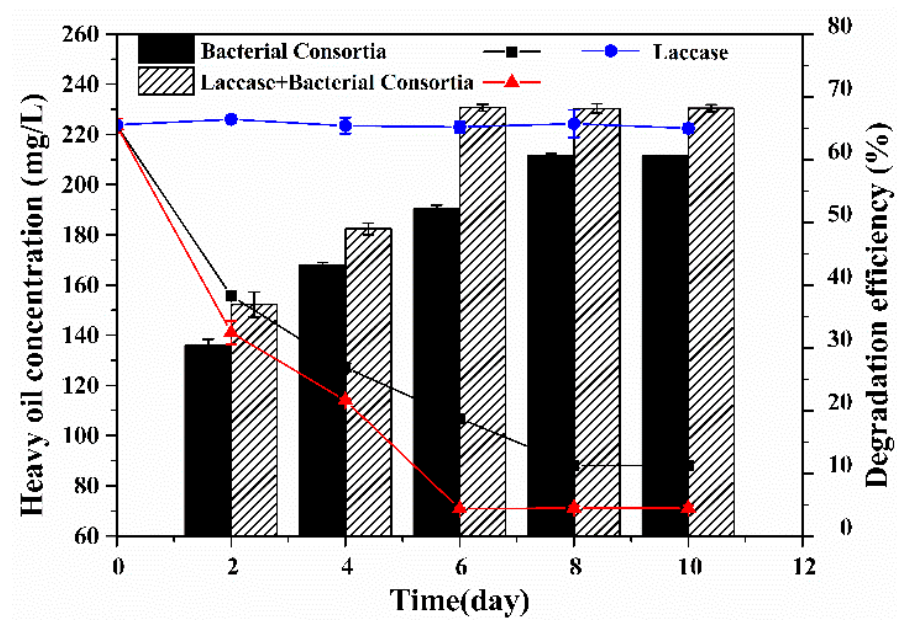

Figure 1. Effect of laccase on heavy oil degradation of bacterial consortia.

\subsection{Biodegradation of Saturated Hydrocarbons of Heavy Oil}

The GC-MS results showed that the laccase-bacterial consortia had a significant removal effect on the saturated hydrocarbons of the heavy oil. On day 6 of the degradation process by the laccase-bacterial consortia, the degradation efficiency of the saturated hydrocarbons increased rapidly to a maximum of $82.4 \pm 0.7 \%$. However, for the bacterial consortia degradation, the degradation efficiency of the saturated hydrocarbons reached the maximum of $66.3 \pm 0.4 \%$ on day 8 . The laccase-bacterial consortia increased the degradation range and degradation rate of the saturated hydrocarbons. The degradation rate constant of the laccase-bacterial consortia for saturated hydrocarbons was 0.267 day $^{-1}$ (Figure $3 b$ ), which was significantly higher than that of the bacterial consortia for saturated hydrocarbons $\left(0.129 \mathrm{day}^{-1}\right)$. 

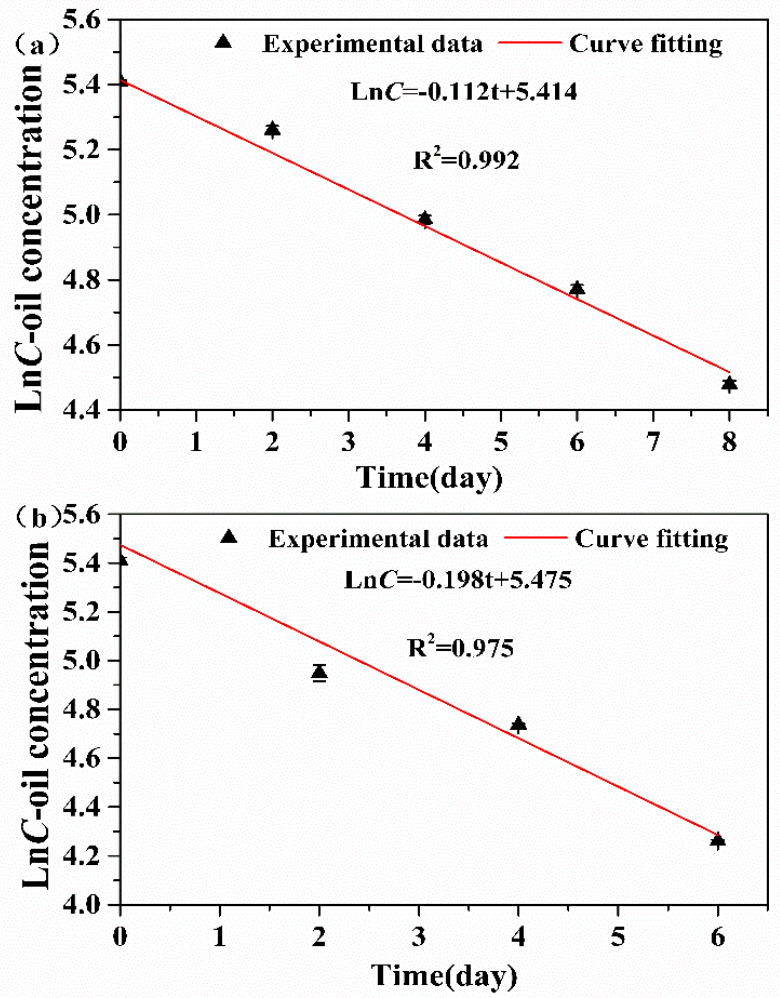

Figure 2. Heavy oil degradation kinetics of the (a) bacterial consortia and (b) laccase-bacterial consortia.
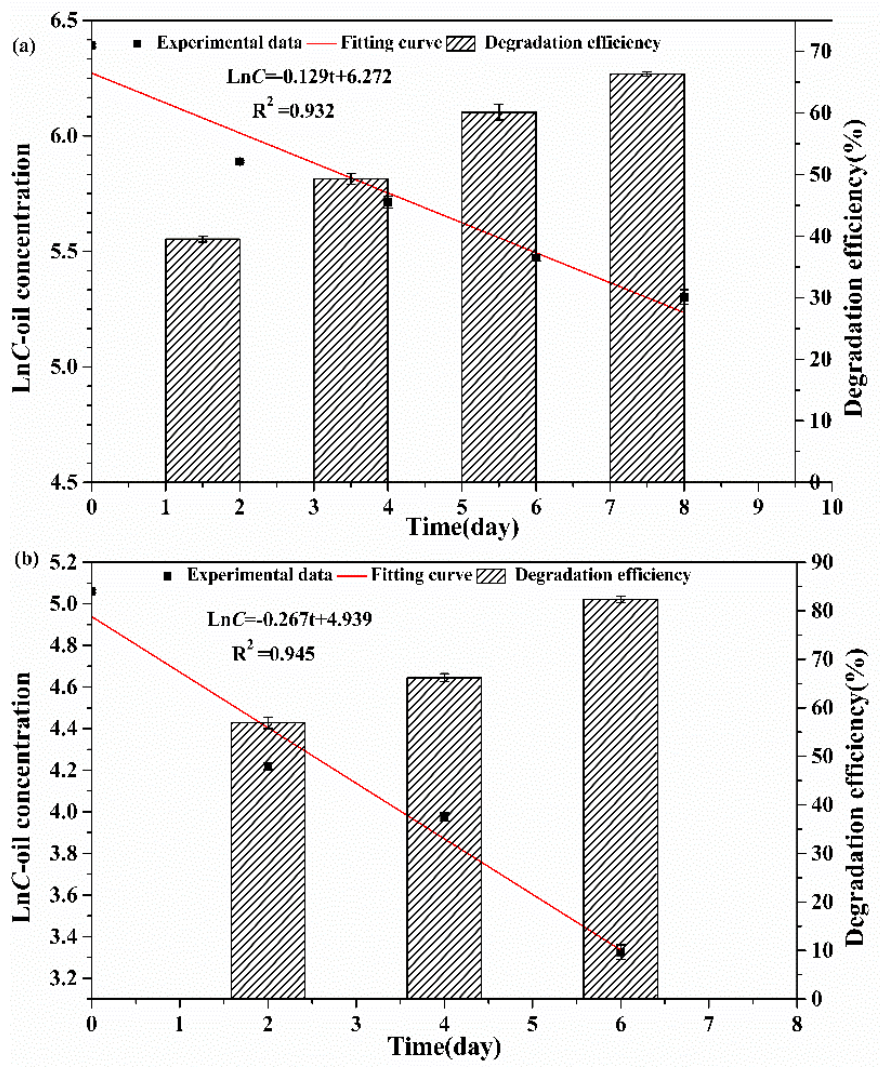

Figure 3. Degradation efficiencies and degradation kinetics of the (a) bacterial consortia and (b) laccase-bacterial consortia for saturated hydrocarbons.

Furthermore, n-alkanes are the most readily degradable components in heavy oil [26] that significantly influence heavy oil degradation efficiency. GC-MS analysis showed 
that the chain length of $n$-alkanes in the experimental heavy oil was mainly between C15 and C35, with C19 and C29 as the main alkanes. The n-alkane abundance in the heavy oil significantly decreased due to the degradation process (Table 1), whereby the degradation efficiency of the laccase-bacterial consortia for C15 to C35 was $80.9 \pm 9.2 \%$ to $100 \%$; moreover, that for C15 to C17 was greater than $94.0 \%$. Compared with the bacterial consortia, the degradation efficiency of C15 to C 35 was significantly increased, especially for $\mathrm{C} 22$ to $\mathrm{C} 35$, the degradation efficiency increased from approximately $60 \%$ to approximately $80 \%$. Based on the above experimental results, it can be inferred that n-alkanes can be used as small molecular mediators to participate in the laccase degradation of polycyclic aromatic hydrocarbons $[18,34]$ and long-chain n-alkanes can also be used as co-metabolic substrates to participate in PAH degradation [35].

Table 1. Degradation efficiencies of the bacterial consortia and laccase-bacterial consortia for C15 to C35 n-alkanes.

\begin{tabular}{|c|c|c|c|c|c|c|}
\hline \multirow[b]{2}{*}{ n-Alkanes } & \multicolumn{3}{|c|}{ Bacterial Consortia Degradation } & \multicolumn{3}{|c|}{ Laccase-Bacterial Consortia Degradation } \\
\hline & $\begin{array}{c}\text { Initial } \\
\text { Abundance }\end{array}$ & $\begin{array}{c}\text { Residual } \\
\text { Abundance }\end{array}$ & $\begin{array}{l}\text { Degradation } \\
\text { Efficiency (\%) }\end{array}$ & $\begin{array}{c}\text { Initial } \\
\text { Abundance }\end{array}$ & $\begin{array}{c}\text { Residual } \\
\text { Abundance }\end{array}$ & $\begin{array}{l}\text { Degradation } \\
\text { Efficiency (\%) }\end{array}$ \\
\hline $\mathrm{C} 15$ & 1.4 & ND & $97.6 \pm 0.9$ & $2.0 \pm 0.4$ & ND & 100 \\
\hline C16 & $6.0 \pm 0.1$ & 0.1 & $98.0 \pm 0.6$ & $4.6 \pm 0.7$ & 0.1 & $98.3 \pm 0.3$ \\
\hline $\mathrm{C} 17$ & $10.4 \pm 0.6$ & 0.8 & $92.4 \pm 0.4$ & $7.4 \pm 0.9$ & $0.4 \pm 0.1$ & $94.0 \pm 0.2$ \\
\hline $\mathrm{C} 18$ & $14.6 \pm 0.3$ & $2.7 \pm 0.1$ & $81.7 \pm 0.5$ & $8.4 \pm 0.7$ & $0.9 \pm 0.1$ & $89.0 \pm 1.5$ \\
\hline C19 & $19.8 \pm 0.5$ & $4.8 \pm 0.5$ & $75.9 \pm 2.1$ & $9.1 \pm 1.6$ & $1.3 \pm 0.4$ & $84.4 \pm 6.5$ \\
\hline $\mathrm{C} 20$ & $26.0 \pm 0.9$ & $7.3 \pm 0.5$ & $72.0 \pm 3.0$ & $10.1 \pm 1.2$ & $1.7 \pm 0.3$ & $83.3 \pm 4.8$ \\
\hline $\mathrm{C} 21$ & $30.5 \pm 1.6$ & $9.1 \pm 0.6$ & $70.2 \pm 3.0$ & $10.3 \pm 1.6$ & $1.8 \pm 0.4$ & $83.0 \pm 1.4$ \\
\hline $\mathrm{C} 22$ & $32.9 \pm 0.7$ & $10.4 \pm 0.9$ & $68.4 \pm 3.1$ & $10.4 \pm 2.0$ & $1.8 \pm 0.3$ & $82.0 \pm 3.4$ \\
\hline $\mathrm{C} 23$ & $37.1 \pm 1.0$ & $12.2 \pm 1.0$ & $67.1 \pm 2.5$ & $10.9 \pm 1.4$ & $1.9 \pm 0.2$ & $81.6 \pm 4.4$ \\
\hline $\mathrm{C} 24$ & $33.5 \pm 1.4$ & $11.7 \pm 0.9$ & $64.9 \pm 4.0$ & $9.9 \pm 1.2$ & $1.7 \pm 0.4$ & $81.6 \pm 6.8$ \\
\hline $\mathrm{C} 25$ & $38.5 \pm 1.0$ & $13.9 \pm 1.0$ & $63.9 \pm 2.4$ & $11.1 \pm 1.0$ & $1.9 \pm 0.2$ & $82.4 \pm 3.5$ \\
\hline $\mathrm{C} 26$ & $30.0 \pm 1.1$ & $10.6 \pm 0.9$ & $64.3 \pm 4.3$ & $9.0 \pm 0.7$ & $1.6 \pm 0.4$ & $82.6 \pm 4.9$ \\
\hline $\mathrm{C} 27$ & $28.0 \pm 0.8$ & $9.9 \pm 0.7$ & $64.6 \pm 3.3$ & $8.3 \pm 0.8$ & $1.4 \pm 0.2$ & $82.7 \pm 1.7$ \\
\hline $\mathrm{C} 28$ & $21.4 \pm 0.6$ & $7.8 \pm 0.7$ & $63.5 \pm 2.3$ & $6.6 \pm 0.5$ & $1.1 \pm 0.2$ & $83.0 \pm 2.4$ \\
\hline C29 & $19.4 \pm 1.0$ & $7.3 \pm 0.7$ & $62.2 \pm 5.3$ & $5.9 \pm 0.8$ & $1.1 \pm 0.2$ & $81.9 \pm 3.7$ \\
\hline C30 & $13.8 \pm 0.8$ & $5.4 \pm 0.5$ & $60.9 \pm 6.3$ & $4.4 \pm 0.9$ & $0.8 \pm 0.2$ & $80.9 \pm 9.2$ \\
\hline C31 & $12.6 \pm 0.8$ & $4.8 \pm 0.5$ & $61.5 \pm 4.4$ & $4.1 \pm 0.6$ & $0.7 \pm 0.1$ & $81.9 \pm 6.2$ \\
\hline C32 & $7.8 \pm 0.7$ & $2.9 \pm 0.4$ & $63.2 \pm 2.3$ & $2.6 \pm 0.4$ & $0.5 \pm 0.3$ & $83.0 \pm 7.1$ \\
\hline C33 & $5.9 \pm 0.6$ & $2.3 \pm 0.3$ & $61.1 \pm 3.3$ & $2.2 \pm 10.1$ & $0.4 \pm 0.1$ & $82.0 \pm 6.3$ \\
\hline C34 & $5.0 \pm 0.4$ & $1.9 \pm 0.4$ & $62.9 \pm 4.4$ & $2.1 \pm 0.4$ & $0.4 \pm 0.1$ & $82.6 \pm 4.8$ \\
\hline C35 & $3.2 \pm 0.5$ & $1.1 \pm 0.2$ & $65.3 \pm 1.0$ & $1.6 \pm 0.4$ & $0.3 \pm 0.1$ & $82.9 \pm 3.7$ \\
\hline
\end{tabular}

ND means "not detected".

\subsection{Biodegradation of the Aromatic Hydrocarbons of Heavy Oil}

Aromatic hydrocarbons, especially PAHs, in heavy oil are the key components limiting heavy oil degradation [26]. On day 6 of degradation by the laccase-bacterial consortia, the degradation efficiency of aromatic hydrocarbons increased rapidly to a maximum of $76.2 \pm 0.9 \%$ (Figure $4 \mathrm{~b}$ ), which was $13.06 \%$ higher than that of the bacterial consortia. The laccase increased the degradation range and degradation rate of aromatic hydrocarbons by the bacterial consortia, which is consistent with the findings of previous studies $[32,36]$. The kinetic constant of the laccase-bacterial consortia for aromatic hydrocarbons was 0.226 day $^{-1}$, which was 2.15 times that of the bacterial consortia for saturated hydrocarbons 
$\left(0.105\right.$ day $\left.^{-1}\right)$ and was higher than that of the bacterial consortia for heavy oil $\left(0.198\right.$ day $\left.^{-1}\right)$. These results showed that aromatic hydrocarbons were not the rate-limiting step of heavy oil degradation by laccase bacteria. It can be inferred that refractory resin and asphaltene are the key components affecting the degradation rate of heavy oil $[37,38]$.
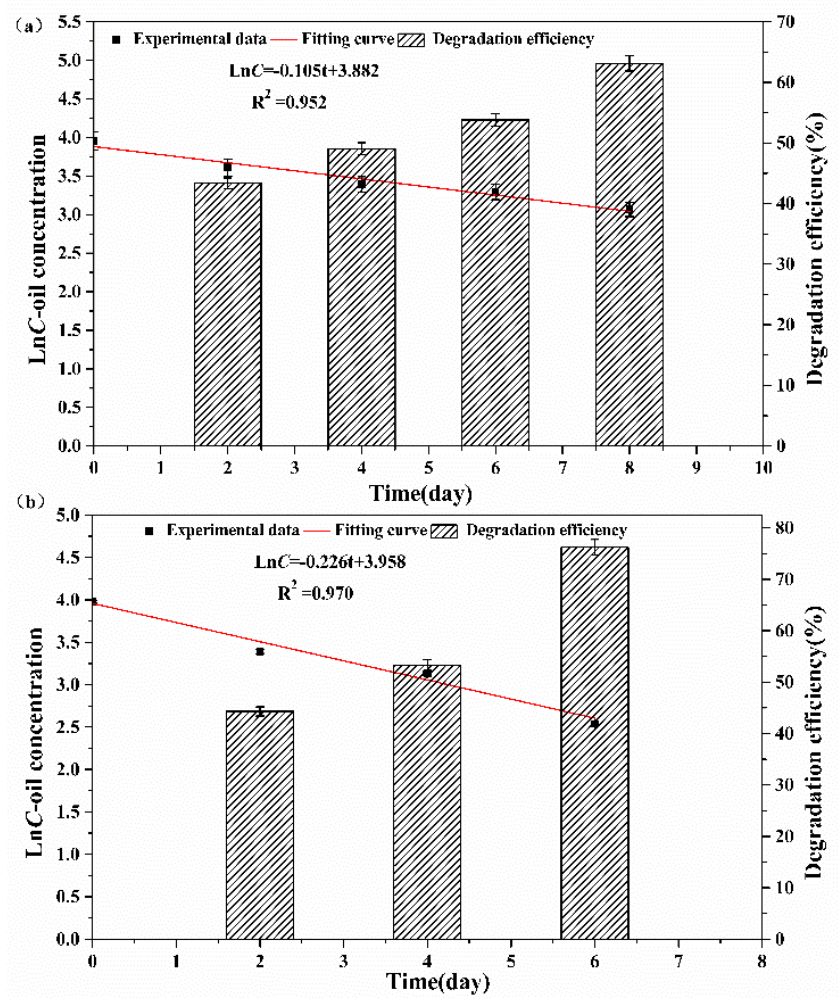

Figure 4. Degradation efficiencies and degradation kinetics of aromatic hydrocarbons for the (a) bacterial consortia and (b) laccase-bacterial consortia.

Polycyclic aromatic hydrocarbons are important components of aromatic hydrocarbons, and they significantly influence the efficiency of heavy oil degradation. The GC-MS analysis showed that the abundance of PAHs in the heavy oil significantly decreased due to the degradation process (Table 2). The degradation efficiencies of the laccase-bacterial consortia for 2-, 3-, 4-, and 5-ring PAHs were 100\%, $65.4 \pm 1.6 \%$ to $95.5 \pm 0.2 \%, 52.4 \pm 8.5 \%$ to $61.9 \pm 0.3 \%$, and $49.9 \pm 3.4 \%$, respectively. Considering the bacterial consortia degradation, the degradation efficiencies for the 2-, 3-, 4-, and 5-ring PAHs were $72.7 \pm 3.6 \%$ to $96.6 \pm 4.8 \%, 54.3 \pm 5.5 \%$ to $87.5 \pm 1.2 \%, 50.2 \pm 2.0 \%$ to $57.3 \pm 6.9 \%$, and $40.8 \pm 1.0 \%$, respectively. The laccase-bacterial consortia significantly improved the PAH degradation compared to the bacterial consortia. These results corroborate those of previous studies [36,39], suggesting that laccase can catalyze the initial oxygenation of PAHs in heavy oil, and the oxidation products are more conducive to microbial biodegradation. 
Table 2. Degradation efficiencies of the bacterial consortia and laccase-bacterial consortia for PAHs.

\begin{tabular}{|c|c|c|c|c|c|c|}
\hline \multirow[b]{2}{*}{ PAHs } & \multicolumn{3}{|c|}{ Bacterial Consortia Degradation } & \multicolumn{3}{|c|}{ Laccase-Bacterial Consortia Degradation } \\
\hline & $\begin{array}{c}\text { Initial } \\
\text { Abundance }\end{array}$ & $\begin{array}{c}\text { Residual } \\
\text { Abundance }\end{array}$ & $\begin{array}{c}\text { Degradation } \\
\text { Efficiency (\%) }\end{array}$ & $\begin{array}{c}\text { Initial } \\
\text { Abundance }\end{array}$ & $\begin{array}{c}\text { Residual } \\
\text { Abundance }\end{array}$ & $\begin{array}{l}\text { Degradation } \\
\text { Efficiency (\%) }\end{array}$ \\
\hline Nap & $0.1 \pm 0.03$ & ND & $96.6 \pm 4.8$ & ND & ND & ND \\
\hline C1-Nap & $0.80 \pm 0.1$ & $0.2 \pm 0.1$ & $77.2 \pm 7.0$ & ND & ND & ND \\
\hline C2-Nap & $1.11 \pm 0.2$ & $0.3 \pm 0.1$ & $76.2 \pm 7.2$ & 0.14 & ND & 100 \\
\hline C3-Nap & $4.0 \pm 0.4$ & $1.0 \pm 0.2$ & $74.0 \pm 5.2$ & $1.7 \pm 0.04$ & ND & 100 \\
\hline C4-Nap & $3.6 \pm 0.5$ & $1.0 \pm 0.2$ & $72.7 \pm 3.6$ & $2.1 \pm 0.1$ & ND & 100 \\
\hline C5-Nap & $0.44 \pm 0.1$ & $0.1 \pm 0.01$ & $74.8 \pm 2.9$ & $1.2 \pm 0.2$ & ND & 100 \\
\hline Phe & $2.66 \pm 0.3$ & $0.7 \pm 0.1$ & $74.9 \pm 3.6$ & $1.8 \pm 0.1$ & $0.1 \pm 0.002$ & $95.5 \pm 0.2$ \\
\hline C1-Phe & $6.6 \pm 0.6$ & $2.8 \pm 0.6$ & $57.1 \pm 9.0$ & $5.4 \pm 0.2$ & $1.1 \pm 0.1$ & $78.6 \pm 2.6$ \\
\hline C2-Phe & $7.66 \pm 0.6$ & $3.5 \pm 0.5$ & $54.3 \pm 5.5$ & $6.4 \pm 0.3$ & $1.7 \pm 0.1$ & $74.0 \pm 1.1$ \\
\hline C3-Phe & $4.4 \pm 0.5$ & $2.0 \pm 0.3$ & $54.6 \pm 3.3$ & $3.8 \pm 0.2$ & $1.3 \pm 0.04$ & $65.4 \pm 1.6$ \\
\hline Flu & $0.2 \pm 0.04$ & $0.03 \pm 0.02$ & $86.2 \pm 6.5$ & $0.1 \pm 0.011$ & ND & 100 \\
\hline C1-Flu & $1.19 \pm 0.25$ & $0.2 \pm 0.04$ & $87.5 \pm 1.2$ & $0.7 \pm 0.1$ & ND & 100 \\
\hline C2-Flu & $2.1 \pm 0.4$ & $0.6 \pm 0.1$ & $70.1 \pm 1.9$ & $1.6 \pm 0.1$ & $0.1 \pm 0.007$ & $94.8 \pm 0.4$ \\
\hline $\mathrm{B}[\mathrm{b}] \mathrm{F}$ & $0.3 \pm 0.1$ & $0.1 \pm 0.03$ & $50.2 \pm 2.0$ & $0.2 \pm 0.02$ & $0.1 \pm 0.01$ & $61.9 \pm 0.3$ \\
\hline Chr & $0.5 \pm 0.2$ & $0.2 \pm 0.1$ & $54.9 \pm 3.0$ & $0.6 \pm 0.04$ & $0.3 \pm 0.02$ & $55.6 \pm 7.7$ \\
\hline C1-Chr & $1.2 \pm 0.2$ & $0.5 \pm 0.1$ & $55.9 \pm 3.8$ & $1.2 \pm 0.1$ & $0.5 \pm 0.02$ & $56.3 \pm 3.3$ \\
\hline C2-Chr & $1.2 \pm 0.3$ & $0.6 \pm 0.1$ & $53.7 \pm 5.9$ & $1.8 \pm 0.2$ & $0.8 \pm 0.1$ & $55.4 \pm 1.0$ \\
\hline Pyr & $0.4 \pm 0.1$ & $0.2 \pm 0.1$ & $57.3 \pm 6.9$ & $0.4 \pm 0.01$ & $0.2 \pm 0.03$ & $57.3 \pm 3.4$ \\
\hline C1-Pyr & $1.0 \pm 0.2$ & $0.5 \pm 0.1$ & $51.1 \pm 1.3$ & $0.9 \pm 0.1$ & $0.4 \pm 0.01$ & $52.4 \pm 8.5$ \\
\hline $\mathrm{B}[\mathrm{e}] \mathrm{P}$ & $0.3 \pm 0.1$ & $0.2 \pm 0.04$ & $40.8 \pm 1.0$ & $0.3 \pm 0.02$ & $0.2 \pm 0.01$ & $49.9 \pm 3.4$ \\
\hline
\end{tabular}

ND means "not detected".

\section{Discussion}

The inoculation of specific bacterial consortia with multiple catabolic genes is a reasonable and feasible strategy for accelerating the efficiency of heavy oil removal from polluted environments [40-43]. However, the presence of PAHs with high toxicity and large molecular weight limits the start-up and biodegradation of the added bacterial consortia $[13,14]$. Therefore, we presume that the rapid degradation of PAHs (the main toxic components of heavy oil) into non-toxic or low toxic substances can quickly start heavy oil biodegradation. Enzymes will be appropriate agents for PAHs rapid degradation as they require neither nutrition from their environment nor necessity for the prevention of predators and toxic substances [18]. Enzymes have been used to biodegrade a broad variety of contaminants, including heavy metals, toxins, dyes, polycyclic aromatic hydrocarbons, and plastics, in place of harsh chemicals [18]. They efficiently degrade the high level of pollutants by utilizing them as substrates.

Laccase can catalyze the initial oxygenation reaction of PAHs degradation; it can convert or transform the PAH compounds into their corresponding quinone forms [44]. However, laccase could not be involved in further oxidation of quinones due to lacking oxidase enzymes. Therefore, its oxidation products need to be further degraded by bacteria consortia [44,45]. In this paper, we investigated the effect of laccase addition on bacterial consortia degradation of heavy oil. The results showed that the laccase can improve degradation efficiency and degradation rate of bacterial degradation of heavy oil by quickly starting the degradation of PAHs in heavy oil. Our research provides an important research idea for the degradation of highly toxic and refractory organic pollutants. 


\section{Conclusions}

In this study, we investigated the effect of laccase on the bacterial consortia degradation of heavy oil. The degradation efficiency of heavy oil was $68.2 \pm 0.6 \%$, with the degradation rate constant of 0.198 day $^{-1}$. The biodegradation efficiency and biodegradation rate of heavy oil was significantly higher $(p<0.05)$ than individual bacterial consortia. The laccase-bacterial consortia could significantly remove saturated hydrocarbons and aromatic hydrocarbons in heavy oil, particularly C15 to C35 n-alkanes and 2 to 5-ring PAHs. The degradation efficiencies for saturated hydrocarbons and aromatic hydrocarbons were $82.4 \pm 0.7 \%$ and $76.2 \pm 0.9 \%$, respectively, with degradation rate constants of 0.267 day $^{-1}$ and 0.226 day $^{-1}$, respectively. It was also found that the addition of laccase significantly promoted the biodegradation of long-chain n-alkanes of C22-C35 $(p<0.05)$. These results show that the addition of laccase can significantly improve the biodegradation efficiency and biodegradation rate of heavy oil. The combined remediation technology of laccase and bacterial consortia has great application potential in both in-situ and ex-situ bioremediation of heavy oil pollution.

Author Contributions: X.D.: conceptualization, investigation, data curation, writing—original draft, writing—review and editing, visualization, supervision; J.L.: methodology, resources; W.W.: investigation, funding acquisition; S.G.: writing—review and editing, funding acquisition, supervision. All authors have read and agreed to the published version of the manuscript.

Funding: This research was funded by the National Key Research and Development Program of China (grant number 2018YFC1801200 and 2018YFC1801301) and Special Project for Reform and Development of Beijing Public Welfare Research Institutes of Beijing Academy of Science and Technology (grant number 2021G-0011).

Institutional Review Board Statement: Not applicable.

Informed Consent Statement: Not applicable.

Data Availability Statement: The data presented in this study are available on request from the corresponding author.

Acknowledgments: We thank Yunyang Wan for the for the experimental materials.

Conflicts of Interest: The authors declare no conflict of interest.

\section{References}

1. Guo, K.; Li, H.L.; Yu, Z.X. In-situ heavy and extra-heavy oil recovery: A review. Fuel 2016, 185, 886-902. [CrossRef]

2. Chen, J.H.; Zhang, W.P.; Wan, Z.; Li, S.F.; Huang, T.C.; Fei, Y.J. Oil spills from global tankers: Status review and future governance. J. Clean. Prod. 2019, 227, 20-32. [CrossRef]

3. Head, J.M.; Jones, D.M.; Röling, W.F.M. Marine microorganisms make a meal of oil. Nat. Rev. Microbiol. 2006, 4, 173-182. [CrossRef] [PubMed]

4. Al-Sayegh, A.; Al-Wahaibi, Y.; Joshi, S.; Al-Bahry, S.; Elshafie, A.; Al-Bemani, A. Bioremediation of heavy crude oil contamination. Open Biotechnol. J. 2016, 10 (Suppl. S2), 301-311. [CrossRef]

5. Jung, D.; Kim, J.A.; Park, M.S.; Yim, U.H.; Choi, K. Human health and ecological assessment programs for Hebei Spirit oil spill accident of 2007: Status, lessons, and future challenges. Chemosphere 2017, 173, 180-189. [CrossRef]

6. Agarwal, A.; Liu, Y. Remediation technologies for oil-contaminated sediments. Mar. Pollut. Bull. 2015, 101, 483-490. [CrossRef]

7. Lee, E.H.; Kim, M.; Moon, Y.S.; Yim, U.H.; Ha, S.Y.; Jeong, C.B.; Lee, J.S.; Jung, J.H. Adverse effects and immune dysfunction in response to oral administration of weathered. Aquat. Toxicol. 2018, 200, 127-135. [CrossRef]

8. Das, R.; Li, G.Y.; Mai, B.X.; An, T.C. Spore cells from BPA degrading bacteria Bacillus sp. GZB displaying high laccase activity and stability for BPA degradation. Sci. Total Environ. 2018, 640-641, 798-806. [CrossRef]

9. Dellagnezze, B.M.; Vasconcellos, S.P.; Angelim, A.L.; Melo, V.M.M.; Santisi, S.; Cappello, S.; Oliveira, V.M. Bioaugmentation strategy employing a microbial consortium immobilized in chitosan beads for oil degradation in mesocosm scale. Mar. Pollut. Bull. 2016, 107, 107-117. [CrossRef]

10. Tao, K.Y.; Zhang, X.Y.; Chen, X.P.; Liu, X.Y.; Hu, X.X.; Yuan, X.Y. Response ofsoil bacterial community to bioaugmentation with a plant residue-immobilized bacterial consortium for crude oil removal. Chemosphere 2019, 222, 831-838. [CrossRef]

11. Al-Bahry, S.N.; Al-Wahaibi, Y.M.; Al-Hinai, B.; Joshi, S.J.; Elshafie, A.E.; Al-Bemani, A.S.; Al-Sabahi, J. Potential in heavy oil biodegradation via enrichment of spore forming bacterial consortia. J. Petrol. Explor. Prod. Technol. 2016, 6, 787-799. [CrossRef] 
12. Alcade, M.; Ferrer, M.; Plou, F.J. Environmental biocatalysis: From remediation with enzymes to novel green processes. Trends Biotechnol. 2006, 24, 281-287. [CrossRef] [PubMed]

13. Saravanan, A.; Senthil Kumar, P.; Vo Dai-Viet, N.; Jeevanantham, S.; Karishma, S.; Yaashika, P.R. A review on catalytic-enzyme degradation of toxic environmental pollutants: Microbial enzymes. J. Hazard. Mater. 2021, 419, 126451. [CrossRef]

14. Kucharzyk, K.H.; Benotti, M.; Darlington, R.; Lalgudi, R. Enhanced biodegradation of sediment-bound heavily weathered crude oil with ligninolytic enzymes encapsulated in calcium-alginate beads. J. Hazard. Mater. 2018, 357, 498-505. [CrossRef]

15. Franciscon, E.; Piubeli, F.; Fantinatti-Garboggini, F.; Menezes, C.R.D.; Silva, I.S.; Cavaco-Paulo, A.; Grossman, M.J.; Durrant, L.R. Polymerization study of the aromatic amines generated by the biodegradation of azo dyes using the laccase enzyme. Enzyme Microb. Technol. 2010, 46, 360-365. [CrossRef]

16. Xu, P.F.; Du, H.; Peng, X.; Tang, Y.; Zhou, Y.Y.; Chen, X.Y.; Fei, J.; Meng, Y.; Yuan, L. Degradation of several polycyclic aromatic hydrocarbons by laccase in reverse micelle system. Sci. Total Environ. 2020, 708, 134970. [CrossRef]

17. Sadeghzadeh, S.; Nejad, Z.G.; Ghasemi, S.; Khafaji, M.; Borghei, S.M. Removal of bisphenol A in aqueous solution using magnetic cross-linked laccase aggregates from Trametes hirsute. Bioresour. Technol. 2020, 306, 123169. [CrossRef]

18. Bilal, M.; Rasheed, T.; Nabeel, F.; Iqbal, H.M.N.; Zhao, Y.P. Hazardous contaminants in the environment and their laccase-assisted degradation-A review. J. Environ. Manag. 2019, 234, 253-264. [CrossRef] [PubMed]

19. Wu, Y.C.; Teng, Y.; Li, Z.G.; Liao, X.W.; Luo, Y.M. Potential role of polycyclic aromatic hydrocarbons (PAHs) oxidation by fungal laccase in the remediation of an aged contaminated soil. Soil Biol. Biochem. 2008, 40, 789-796. [CrossRef]

20. Bautista, L.F.; Morales, G.; Sanz, R. Biodegradation of polycyclic aromatic hydrocarbons (PAHs) by laccase from Trametes versicolor covalently immobilized on amino-functionalized SBA-15. Chemosphere 2015, 136, 273-280. [CrossRef] [PubMed]

21. Liu, B.Q.; Liu, J.P.; Ju, M.T.; Li, X.J.; Wang, P. Bacteria-white-rot fungi joint remediation of petroleum-contaminated soil based on sustained release of laccase. RSC Adv. 2017, 7, 39075-39081. [CrossRef]

22. Dai, X.L.; Lv, J.; Guo, S.H.; Wei, W.X. Heavy oil biodegradation by mixed bacterial consortium of biosurfactant-producing and heavy oil-degrading bacteria. Pol. J. Environ. Stud. 2021, 30, 71-80. [CrossRef]

23. China, M.E.P. Water Quality-Determination of Petroleum Oil, Animal and Vegetable Oils-Infrared Photometric Method (HJ 637-2012); Chinese Ministry of Environmental Protection: Beijing, China, 2012.

24. Dai, X.L.; Yan, G.X.; Guo, S.H. Characterization of Dietzia cercidiphylli C-1 isolated from extra-heavy oil contaminated soil. RSC Adv. 2017, 7, 19486. [CrossRef]

25. Chettri, B.; Singh, A.K. Kinetics of hydrocarbon degradation by a newly isolated heavy metal tolerant bacterium Novosphingobium panipatense P5:ABC. Bioresour. Technol. 2019, 294, 122190. [CrossRef]

26. Varjani, S.J. Microbial degradation of petroleum hydrocarbons. Bioresour. Technol. 2017, 223, 277-286. [CrossRef] [PubMed]

27. Cai, B.; Ma, J.; Yan, G.X.; Dai, X.L.; Li, M.; Guo, S.H. Comparison of phytoremediation, bioaugmentation and naturalattenuation for remediating saline soil contaminated by heavy crude oil. Biochem. Eng. J. 2016, 112, 170-177. [CrossRef]

28. Navada, K.K.; Kulal, A. Enzymatic degradation of chloramphenicol by laccase from Trametes hirsute and comparison among mediators. Int. Biodeterior. Biodegrad. 2019, 13, 63-69. [CrossRef]

29. Imam, A.; Suman, S.K.; Singh, R.; Vempatapu, B.P.; Ray, A.; Kanaujia, P.K. Application of laccase immobilized rice straw biochar for anthracene degradation. Environ. Pollut. 2021, 268, 115827. [CrossRef]

30. Sun, J.N.; Zheng, M.X.; Lu, Z.X.; Lu, F.X.; Zhang, C. Heterologous production of a temperature and pH-stable laccase from Bacillus vallismortis fmb-103 in Escherichia coli and its application. Process. Biochem. 2017, 55, 77-84. [CrossRef]

31. Xu, K.Z.; Ma, H.; Wang, Y.J.; Cai, Y.J.; Liao, X.R.; Guan, Z.B. Extracellular expression of mutant CotA-laccase SF in Escherichia coliand itsdegradation of malachite green. Ecotoxicol. Environ. Saf. 2020, 193, 110335. [CrossRef]

32. Harms, H.; Schlosser, D.; Wick, L.Y. Untapped potential: Exploiting fungi in bioremediation of hazardous chemicals. Nat. Rev. Microbiol. 2011, 9, 177-192. [CrossRef] [PubMed]

33. Xue, J.L.; Yu, Y.; Bai, Y.; Wang, L.P.; Wu, Y.A. Marine oil-degrading microorganisms and biodegradation process of petroleum hydrocarbon in marine environments: A review. Curr. Microbiol. 2015, 71, 220-228. [CrossRef]

34. Asadi, E.; Makhdoumi, A.; Asoodeh, A. Laccase mediator system obtained from a marine spore exhibits decolorization potential in harsh environmental conditions. Ecotoxicol. Environ. Saf. 2020, 191, 110184. [CrossRef]

35. Arulazhagan, P.; Sivaraman, C.; Kumar, S.A.; Aslam, M.; Banu, J.R. Co-metabolic degradation of benzo (e) pyrene by halophilic bacterial consortium at different saline conditions. J. Environ. Biol. 2014, 35, 445. [CrossRef]

36. Kadri, T.; Rouissi, T.; Brar, S.K.; Cledon, M.; Sarma, S.; Verma, M. Biodegradation of polycyclic aromatic hydrocarbons (PAHs) by fungal enzymes: A review. J. Environ. Sci. (China) 2017, 51, 52-74. [CrossRef] [PubMed]

37. Zoueki, C.W.; Ghoshal, S.; Tufenkji, N. Bacterial adhesion to hydrocarbons: Role of asphaltenes and resins. Colloids Surf. B 2010, 79, 219-226. [CrossRef]

38. Hernandez-Lopez, E.L.; Ayala, M.; Vazquez-Duhalt, R. Microbial and enzymatic biotransformations of asphaltenes. Pet. Sci. Technol. 2015, 33, 1017-1029. [CrossRef]

39. Fuentes, S.; Méndez, V.; Aguila, P.; Seeger, M. Bioremediation of petroleum hydrocarbons: Catabolic genes, microbial communities, and applications. Appl. Microbiol. Biotechnol. 2014, 98, 4781-4794. [CrossRef]

40. Varjani, S.J.; Rana, D.P.; Jain, A.K.; Bateja, S.; Upasani, V.N. Synergistic ex-situ biodegradation of crude oil by halotolerant bacterial consortium of indigenous strains isolated from on shore sites of Gujarat, India. Int. Biodeterior. Biodegrad. 2015, 103, 116-124. [CrossRef] 
41. Chen, Q.; Li, J.; Liu, M.; Sun, H.; Bao, M. Study on the biodegradation of crude oil by free and immobilized bacterial consortium in marine environment. PLOS ONE 2017, 12, e0174445. [CrossRef]

42. Tao, K.; Liu, X.; Chen, X.; Hu, X.; Cao, L.; Yuan, X. Biodegradation of crude oil by a defined co-culture of indigenous bacterial consortium and exogenous Bacillus subtilis. Bioresour. Technol. 2017, 224, 327-332. [CrossRef] [PubMed]

43. Zhang, X.; Kong, D.; Liu, X.; Xie, H.; Lou, X.; Zeng, C. Combined microbial degradation of crude oil under alkaline conditions by Acinetobacter baumannii and Talaromyces sp. Chemosphere 2021, 273, 129666. [CrossRef] [PubMed]

44. Pozdnyakova, N.; Dubrovskaya, E.; Chernyshova, M.; Makarov, O.; Golubev, S.; Balandina, S.; Turkovskaya, O. The peculiarities of degradation of three ringed polycyclic aromatic hydrocarbons by wood-inhabiting fungus Pleurotus ostreatus and soil-inhabiting fungus Agaricus bisporus. Fungal Biol. 2018, 122, 363-372. [CrossRef]

45. Boonchan, S.; Britz, M.L.; Stanley, G.A. Degradation and mineralization of high-molecular-weight polycyclic aromatic hydrocarbons by defined fungal-bacterial cocultures. Appl. Environ. Microbiol. 2000, 66, 1007-1019. [CrossRef] [PubMed] 